\title{
New Determination Methods of Halides and Cyanide Ions by Electrospray Ionization Mass Spectrometry Based on Ternary Complex Formation
}

\author{
Hiroki Hotta, ${ }^{*}$ Shota Kurihara, ${ }^{* *}$ Keita Johno, ${ }^{* *}$ Masaomi Kitazume, ${ }^{* *}$ Kiichi Sato, ${ }^{* *}$ and \\ Kin-Ichi TsunODA**†
}

*Department of Chemistry, Nara University of Education, Takabatake, Nara 630-8528, Japan

**Department of Chemistry and Chemical Biology, Gunma University, Kiryu 376-8515, Japan

\begin{abstract}
Determination methods of halide ions $\left(\mathrm{X}^{-}=\mathrm{F}^{-}, \mathrm{Cl}^{-}, \mathrm{Br}^{-}\right.$and $\left.\mathrm{I}^{-}\right)$by electrospray ionization mass spectrometry (ESIMS) were developed, where negative ions of the ternary complexes of group-13 elements, nitrilotriacetic acid (NTA), and halides were measured. In particular, these halides were simultaneously determined by measuring [InX(nta) ] $]^{-}$, and the limits of detection (LODs) were $1.1 \mu \mathrm{mol} \mathrm{dm}{ }^{-3}$ for F-, $0.32 \mu \mathrm{mol} \mathrm{dm}{ }^{-3}$ for $\mathrm{Cl}^{-}, 3.8 \mathrm{nmol} \mathrm{dm}^{-3}$ for $\mathrm{Br}^{-}$, and $1.6 \mathrm{nmol} \mathrm{dm}^{-3}$ for $\mathrm{I}^{-}$, respectively. This approach was extended to the determination of $\mathrm{CN}^{-}$, where the ternary complex of $\mathrm{Cu}^{\mathrm{II}}, \mathrm{CN}^{-}$and

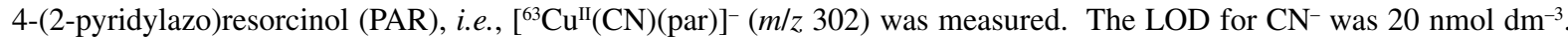

(Received June 10, 2011; Accepted August 9, 2011; Published September 10, 2011)

\section{Introduction}

Recently, electrospray ionization mass spectrometry (ESIMS) has been applied to determine various inorganic anions, mainly as an IC-MS or LC-MS system. ${ }^{1-5}$ In particular, perchlorate ion in environmental samples has been an important target for these methods..$^{2-4}$ Moreover, Minakata et al. reported the determination methods of $\mathrm{CN}^{-}$and $\mathrm{I}^{-}$by ESIMS/MS, where $\mathrm{Au}(\mathrm{CN})_{2}{ }^{-}$and $\mathrm{AuI}_{2}{ }^{-}$were measured after their ion-pair extraction into 4-methyl-2-pentanone, respectively. ${ }^{6,7}$ We have also proposed a new method for quantitative trace analyses of fluoride ion by ESIMS, where the ternary complex of aluminum, fluoride and nitrilotriacetic acid (NTA), i.e., $[\mathrm{AlF}(\mathrm{nta})]^{-}$, was measured for the determination of fluoride. The limit of detection (LOD) of this method is $10 \mathrm{nmol} \mathrm{dm}^{-3}$, and currently it is one of the most sensitive methods for $\mathrm{F}^{-8} .8$

In this study, we extended this approach to the determination of other halide ions $\left(\mathrm{X}^{-}=\mathrm{Cl}^{-}, \mathrm{Br}^{-}\right.$and $\left.\mathrm{I}^{-}\right)$, where negative ions of the ternary complexes of group-13 elements, NTA, and halides were measured by ESIMS. In particular, these halides were simultaneously determined by measuring $[\operatorname{InX}(\mathrm{nta})]^{-}$. Although their LODs were reported in Ref. 8 very briefly, the methods have not yet been described. Moreover, the ternary complex formation of copper(II), $\mathrm{CN}^{-}$and 4-(2-pyridylazo)resorcinol (PAR), i.e., $\left[{ }^{63} \mathrm{Cu}^{\mathrm{II}}(\mathrm{CN})(\mathrm{par})\right]^{-}(\mathrm{m} / \mathrm{z}, 302)$, was utilized for the determination of $\mathrm{CN}^{-}$.

\section{Experimental}

\section{Reagents and chemicals}

Nitrilotriacetic acid (NTA), 4-(2-pyridylazo)resorcinol (PAR) and 2-(5-bromo-2-pyridylazo)-5-[ $N$ - $n$-propyl- $N$-(3-sulfopropyl)-

$\dagger$ To whom correspondence should be addressed.

E-mail: hotta@nara-edu.ac.jp amino]phenol, disodium salt, dehydrate (5-Br-PAPS) were obtained from Dojindo Laboratories, Japan. Other reagents of analytical grade were from Wako Pure Chemicals, Japan. All metal ions $\left(\mathrm{In}^{3+}, \mathrm{Ga}^{3+}, \mathrm{Cu}^{2+}\right.$, etc. $)$ were used as nitrate salts. Potassium salts or sodium salts were used as standards of anions. Water was purified by a Millipore Milli-Q system (Millipore Corp., USA).

\section{Apparatus}

The LC-ESI-quadrupole MS system, LCMS-2010A (Shimadzu Co., Japan), was used in the flow-injection mode. The negativeion mode was used throughout this study. The instrumental conditions were as follows: electrospray voltage, $-3.5 \mathrm{kV}$; Q-array voltage, $-50 \mathrm{~V}$; nebulizer gas $\left(\mathrm{N}_{2}\right)$ pressure, $0.1 \mathrm{MPa}$; the curve desolvation line $(\mathrm{CDL})$ temperature, $300^{\circ} \mathrm{C}$; block heater temperature, $200^{\circ} \mathrm{C}$. Sample solutions were introduced with a six-way loop injector whose sample loop volume was $30 \mathrm{~mm}^{3}$. Pure water was used as a carrier solution (flow rate, $\left.0.2 \mathrm{~cm}^{3} \mathrm{~min}^{-1}\right)$.

\section{Measurement procedures}

Determination of halides by ESIMS. A sample solution containing $200 \mu \mathrm{mol} \mathrm{dm}{ }^{-3}$ of $\mathrm{In}^{3+}, 200 \mu \mathrm{mol} \mathrm{dm}{ }^{-3}$ of NTA, $1 \mathrm{mmol} \mathrm{dm}^{-3}$ of ammonium acetate, appropriate concentrations of halide ion $\left(\mathrm{X}^{-}=\mathrm{F}^{-}, \mathrm{Cl}^{-}, \mathrm{Br}^{-}\right.$, and/or $\left.\mathrm{I}^{-}\right)$as well as $20 \mu \mathrm{mol} \mathrm{\textrm {dm } ^ { - 3 }}$ of $\left[\mathrm{Co}^{\mathrm{III}}(\mathrm{edta})\right]^{-}$as an internal standard was prepared for ESIMS measurements. The $\mathrm{pH}$ of the solution was adjusted to 3 to 4 by the addition of a nitric acid or ammonia aqueous solution. The $\mathrm{pH}$ values of the test solution, except for the $\mathrm{Cl}^{-}$measurement, were checked by a conventional $\mathrm{pH}$ meter (Horiba Co., Japan). In the case of the $\mathrm{Cl}^{-}$measurement, the $\mathrm{pH}$ values were checked by a separate $\mathrm{pH}$ sensitive electrode with a $\mathrm{Hg}_{2} \mathrm{SO}_{4}$ reference electrode so as to avoid any contamination by the oozing of $\mathrm{Cl}^{-}$ from an $\mathrm{Ag} / \mathrm{AgCl}$ electrode. The ion intensities of [ $\mathrm{InF}(\mathrm{nta})]^{-}$ (m/z 322), $\left[\mathrm{In}^{35} \mathrm{Cl}(\mathrm{nta})\right]^{-}(\mathrm{m} / \mathrm{z} 338),\left[\operatorname{In}^{79} \mathrm{Br}(\mathrm{nta})\right]^{-}(\mathrm{m} / \mathrm{z} 382)$, and $[\mathrm{InI}(\mathrm{nta})]^{-}(\mathrm{m} / \mathrm{z}, 430)$ as well as that of $\left[\mathrm{Co}^{\mathrm{III}}(\text { edta })\right]^{-}(\mathrm{m} / \mathrm{z}, 347)$ were simultaneously monitored for their determination with the 
Table 1 Limits of detection (LODs) for halides and cyanide by ESIMS

\begin{tabular}{clc}
\hline Analyte & \multicolumn{1}{c}{ Ternary complex $(\mathrm{m} / \mathrm{z})$} & $\mathrm{LOD}^{\mathrm{a}} / \mathrm{nmol} \mathrm{dm}^{-3}$ \\
\hline $\mathrm{F}^{-}$ & {$[\mathrm{AlF}(\mathrm{nta})]^{-}(\mathrm{m} / \mathrm{z}, 234)$} & $10^{\mathrm{b}}$ \\
& {$[\mathrm{InF}(\mathrm{nta})]^{-}(\mathrm{m} / \mathrm{z}, 322)$} & $1.1 \times 10^{3}$ \\
$\mathrm{Cl}^{-}$ & {$\left[{ }^{69} \mathrm{Ga}^{35} \mathrm{Cl}(\mathrm{nta})\right]^{-}(\mathrm{m} / \mathrm{z}, 292)$} & $2.3 \times 10^{3}$ \\
& {$\left[\mathrm{In}^{35} \mathrm{Cl}(\mathrm{nta})\right]^{-}(\mathrm{m} / \mathrm{z}, 338)$} & $310^{\mathrm{c}}$ \\
$\mathrm{Br}$ & {$\left[{ }^{69} \mathrm{Ga}{ }^{79} \mathrm{Br}(\mathrm{nta})\right]^{-}(\mathrm{m} / \mathrm{z}, 336)$} & 93 \\
& {$\left[\mathrm{In}{ }^{79} \mathrm{Br}(\mathrm{nta})\right]^{-}(\mathrm{m} / \mathrm{z} 382)$} & $3.8^{\mathrm{c}}$ \\
$\mathrm{I}^{-}$ & {$[\mathrm{InI}(\mathrm{nta})]^{-}(\mathrm{m} / \mathrm{z}, 430)$} & $1.6^{\mathrm{c}}$ \\
$\mathrm{CN}^{-}$ & {$\left[{ }^{63} \mathrm{Cu} \mathrm{u}^{\mathrm{II}}(\mathrm{CN})(\mathrm{par})\right]^{-}(\mathrm{m} / \mathrm{z}, 302)$} & 20 \\
& {$\left[{ }^{63} \mathrm{Cu}(\mathrm{CN})(5-\mathrm{Br}-\mathrm{paps})\right]^{-}(\mathrm{m} / \mathrm{z}, 545)$} & 230 \\
\hline
\end{tabular}

a. $3 \sigma$ of background signals

b. This value was reported in Ref. 8 .

c. These values were reported in Ref. 8 very briefly.

SIM (selected ion monitoring) mode, respectively.

Determination of cyanide ion by ESIMS. A sample solution containing $20 \mu \mathrm{mol} \mathrm{dm}{ }^{-3}$ of $\mathrm{Cu}^{2+}, 50 \mu \mathrm{mol} \mathrm{dm}{ }^{-3}$ of PAR, $1 \mathrm{mmol} \mathrm{dm}^{-3}$ of ammonium acetate, an appropriate concentration of $\mathrm{CN}^{-}$(up to $10 \mu \mathrm{mol} \mathrm{dm}{ }^{-3}$ ) as well as $20 \mu \mathrm{mol} \mathrm{dm}{ }^{-3}$ of $\left[\mathrm{Co}^{\text {III }}(\text { edta })\right]^{-}(\mathrm{m} / \mathrm{z}, 347)$ as an internal standard was prepared for ESIMS measurements. The ion intensity of $\left[{ }^{63} \mathrm{Cu}^{\mathrm{II}}(\mathrm{CN})(\text { par })\right]^{-}$ $(\mathrm{m} / \mathrm{z}, 302)$ as well as that of $\left[\mathrm{Co}^{\mathrm{III}}(\text { edta) }]^{-}(\mathrm{m} / \mathrm{z}, 347)\right.$ were simultaneously monitored for the determination of $\mathrm{CN}^{-}$with the SIM mode. The solution $\mathrm{pH}$ was adjusted to 7 to 9 with the addition of dilute ammonia water, and there was no change in the ESIMS intensity observed in this range.

\section{Results and Discussion}

ESIMS spectra of the ternary complexes of 13 group elements, halides and NTA

Since $\mathrm{Cl}^{-}, \mathrm{Br}^{-}$and $\mathrm{I}^{-}$are much softer Lewis bases than $\mathrm{F}^{-}$, we selected gallium ion and indium ion as center metal ions, which are softer Lewis acids than aluminum ion. Firstly, the ESIMS spectra (negative-ion mode) of $[\mathrm{GaCl}(\mathrm{nta})]^{-}$and $[\mathrm{GaBr}(\mathrm{nta})]^{-}$, $[\mathrm{InCl}(\mathrm{nta})]^{-}$and $[\mathrm{InBr}(\mathrm{nta})]^{-}$were measured, and were compared with one another. Although both metals gave linear responses to these halide ions, the sensitivity was better for $\mathrm{In}^{\mathrm{III}}$ complexes than for $\mathrm{Ga}^{\mathrm{III}}$ complexes, as shown in Table 1. This may partly be due to their isotopes: indium has one main isotope $\left({ }^{115} \mathrm{In}\right.$, $96 \%$ ), while gallium has two main isotopes $\left({ }^{69} \mathrm{Ga}, 60 \% ;{ }^{71} \mathrm{Ga}\right.$, $40 \%)$. Thus, we further studied the ESIMS spectra of $[\mathrm{InX}(\mathrm{nta})]^{-}$. Figure 1 shows the ESIMS spectra of [InX(nta) $]^{-}$ $\left(\mathrm{X}^{-}=\mathrm{F}^{-}, \mathrm{Cl}^{-}, \mathrm{Br}^{-}\right.$and $\left.\mathrm{I}^{-}\right)$. As shown in the figure, $[\mathrm{InF}(\mathrm{nta})]^{-}$ (m/z 322), $\left[\operatorname{In}^{35} \mathrm{Cl}(\mathrm{nta})\right]^{-}(\mathrm{m} / \mathrm{z} 338),\left[\operatorname{In}^{37} \mathrm{Cl}(\mathrm{nta})\right]^{-}(\mathrm{m} / \mathrm{z}, 340)$, $\left[\operatorname{In}^{79} \operatorname{Br}(\mathrm{nta})\right]^{-} \quad(\mathrm{m} / \mathrm{z} \quad 382), \quad\left[\operatorname{In}^{81} \operatorname{Br}(\mathrm{nta})\right]^{-} \quad(\mathrm{m} / \mathrm{z} \quad 384), \quad$ and $\left[\operatorname{In}^{127} \mathrm{I}(\mathrm{nta})\right]^{-}(\mathrm{m} / \mathrm{z}, 430)$ as well as $\left[\mathrm{Co}^{\mathrm{III}}(\text { edta })\right]^{-}(\mathrm{m} / \mathrm{z}, 347)$ were observed. Moreover, the optimum conditions of the sample solutions for the $\mathrm{pH}$ and the concentrations of $\operatorname{In}^{3+}$ and NTA were examined. When the excess amounts of NTA over $\mathrm{In}^{3+}$ were added to the sample, free NTA ions interfered with the ESIMS measurements of the ternary complexes. That is, a considerable depression of [InX(nta) $]^{-}$signals were observed, when $200 \mu \mathrm{mol} \mathrm{dm}{ }^{-3}$ of $\mathrm{In}^{3+}$ and $500 \mu \mathrm{mol} \mathrm{dm}{ }^{-3}$ of NTA were added to the solutions. Thus, equal amounts of $\operatorname{In}^{3+}$ and NTA were added to the samples. The range of $\mathrm{pH} 3$ to 4 was the most suitable for the measurements. Based on these optimizations, $\mathrm{F}^{-}, \mathrm{Cl}^{-}, \mathrm{Br}^{-}$, and $\mathrm{I}^{-}$were determined simultaneously, as shown in Fig. 2. The LODs for these halides

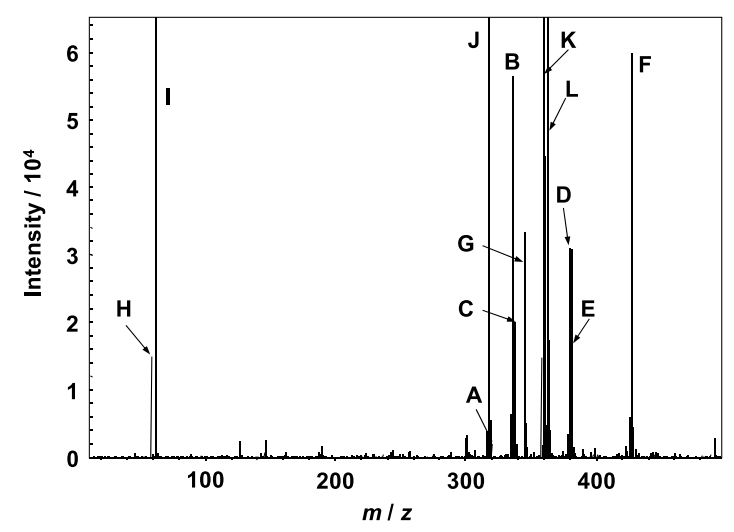

Fig. 1 ESI mass spectrum of $[\operatorname{InX}(n t a)]^{-}$. The sample solution contains $200 \mu \mathrm{mol} \mathrm{dm}{ }^{-3}$ of $\operatorname{In}^{3+}, 200 \mu \mathrm{mol} \mathrm{dm}{ }^{-3}$ of NTA, $1 \mathrm{mmol} \mathrm{dm}^{-3}$ of ammonium acetate, $5 \mu \mathrm{mol} \mathrm{dm}{ }^{-3}$ of halide ions $\left(\mathrm{X}^{-}=\mathrm{F}^{-}, \mathrm{Cl}^{-}, \mathrm{Br}\right.$ and $\left.\mathrm{I}^{-}\right)$as well as $20 \mu \mathrm{mol} \mathrm{dm}{ }^{-3}$ of [Co $\mathrm{Co}^{\mathrm{III}}(\text { edta }]^{-}$as an internal standard. A, [InF(nta) $]^{-}(\mathrm{m} / \mathrm{z} 322) ; \mathrm{B},\left[\mathrm{In}^{35} \mathrm{Cl}(\mathrm{nta})\right]^{-}(\mathrm{m} / \mathrm{z}, 338) ; \mathrm{C},\left[\mathrm{In}^{37} \mathrm{Cl}(\mathrm{nta})\right]^{-}$ (m/z 340); D, [In $\left.{ }^{79} \operatorname{Br}(\mathrm{nta})\right]^{-}(\mathrm{m} / z, 382) ; \mathrm{E},\left[\mathrm{In}^{81} \mathrm{Br}(\mathrm{nta})\right]^{-}(\mathrm{m} / \mathrm{z}, 384) ; \mathrm{F}$, [InI(nta)] $]^{-}\left(\mathrm{m} / \mathrm{z}\right.$ 430); $\mathrm{G},\left[\mathrm{Co}^{\mathrm{III}}(\mathrm{edta})\right]^{-}(\mathrm{m} / \mathrm{z}, 347) ; \mathrm{H}, \mathrm{CH}_{3} \mathrm{COO}^{-}(\mathrm{m} / \mathrm{z}$ $59) ;{\mathrm{I}, \mathrm{NO}_{3}-}^{-}(\mathrm{m} / \mathrm{z}, 62) ; \mathrm{J},[\mathrm{In}(\mathrm{OH})(\mathrm{nta})]^{-}(\mathrm{m} / \mathrm{z} 320) ; \mathrm{K},\left[\mathrm{In}\left(\mathrm{CH}_{3} \mathrm{COO}\right)(\mathrm{nta})\right]^{-}$ $(\mathrm{m} / \mathrm{z}, 362) ; \mathrm{L},\left[\mathrm{In}\left(\mathrm{NO}_{3}\right)(\mathrm{nta})\right]^{-}(\mathrm{m} / \mathrm{z}, 365)$.

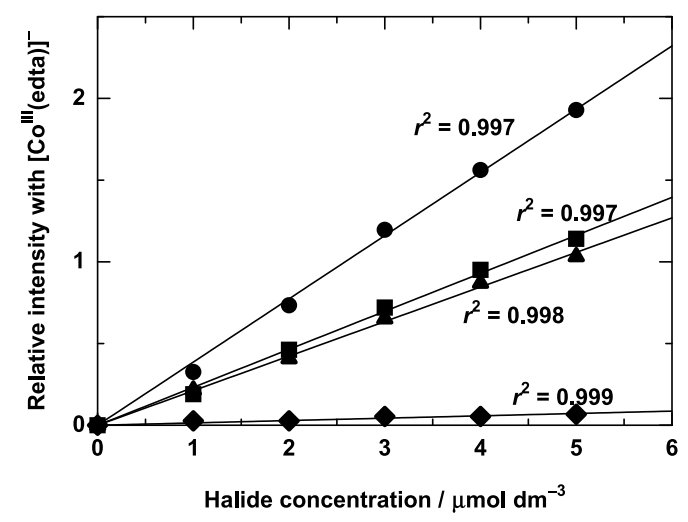

Fig. 2 Simultaneous determination of $\mathrm{F}^{-}, \mathrm{Cl}^{-}, \mathrm{Br}^{-}$and $\mathrm{I}^{-}$by ESIMS with $[\operatorname{InX}(\mathrm{nta})]^{-}$measurements. Each sample solution contains $200 \mu \mathrm{mol} \mathrm{dm}^{-3}$ of $\mathrm{In}^{3+}, 200 \mu \mathrm{mol} \mathrm{dm}^{-3}$ of NTA, $1 \mathrm{mmol} \mathrm{dm}^{-3}$ of ammonium acetate, zero to $5 \mu \mathrm{mol} \mathrm{dm}{ }^{-3}$ of halide ions $\left(\mathrm{X}^{-}=\mathrm{F}^{-}, \mathrm{Cl}^{-}\right.$,

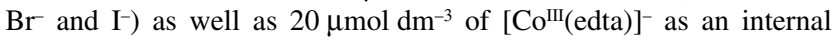
standard. The signal intensities of $[\operatorname{InF}(\mathrm{nta})]^{-}(\diamond, \mathrm{m} / \mathrm{z} 322)$ $\left[\mathrm{In}{ }^{35} \mathrm{Cl}(\mathrm{nta})\right]^{-}(\boldsymbol{\square}, \mathrm{m} / \mathrm{z} 338),\left[\operatorname{In}{ }^{79} \mathrm{Br}(\mathrm{nta})\right]^{-}(\boldsymbol{\bullet}, \mathrm{m} / \mathrm{z}, 382)$, and $[\mathrm{InI}(\mathrm{nta})]^{-}$ $(\bullet, m / z, 430)$ as well as that of $\left[\mathrm{Co}^{\mathrm{III}}(\mathrm{edta})\right]^{-}(\mathrm{m} / \mathrm{z}, 347)$ were simultaneously monitored with SIM mode.

are also summarized in Table 1 . As for $\mathrm{F}^{-},[\operatorname{InF}(\mathrm{nta})]^{-}(\mathrm{m} / z$ 322) gave a far lower sensitivity than $[\operatorname{AlF}(n t a)]^{-}(m / z 234)$. This result should be reasonable considering the stabilities of the two ternary complexes. Although the LOD of $\mathrm{Cl}^{-}$was not as low as expected, it was mainly due to the contamination of $\mathrm{Cl}^{-}$. As a matter of fact, as shown in Fig. 2, the slope of $\left[\mathrm{In}^{35} \mathrm{Cl}(\mathrm{nta})\right]^{-}(\mathrm{m} / \mathrm{z}$ 338) was almost the same as that of $\left[\operatorname{In}^{79} \mathrm{Br}(\mathrm{nta})\right]^{-}(\mathrm{m} / \mathrm{z}, 382)$. The LODs for $\mathrm{Br}^{-}$and $\mathrm{I}^{-}$in this method were very low, as shown in Table 1. The LODs of conventional methods for $\mathrm{Cl}^{-}, \mathrm{Br}^{-}$and $\mathrm{I}^{-}$, such as ion chromatography (IC), ion-selective electrode methods (ISEs) and spectrophotometries are no lower than $0.1 \mu \mathrm{mol} \mathrm{dm}{ }^{-3} .9,10$ Thus, the present methods could be classified as being highly sensitive techniques. The upper limits of the calibration curves were $20 \mu \mathrm{mol} \mathrm{dm}{ }^{-3}$ for $\mathrm{F}^{-}, 50 \mu \mathrm{mol} \mathrm{dm}{ }^{-3}$ for $\mathrm{Cl}^{-}$, and $10 \mu \mathrm{mol} \mathrm{dm}{ }^{-3}$ for $\mathrm{Br}^{-}$and $\mathrm{I}^{-}$, respectively. This method 


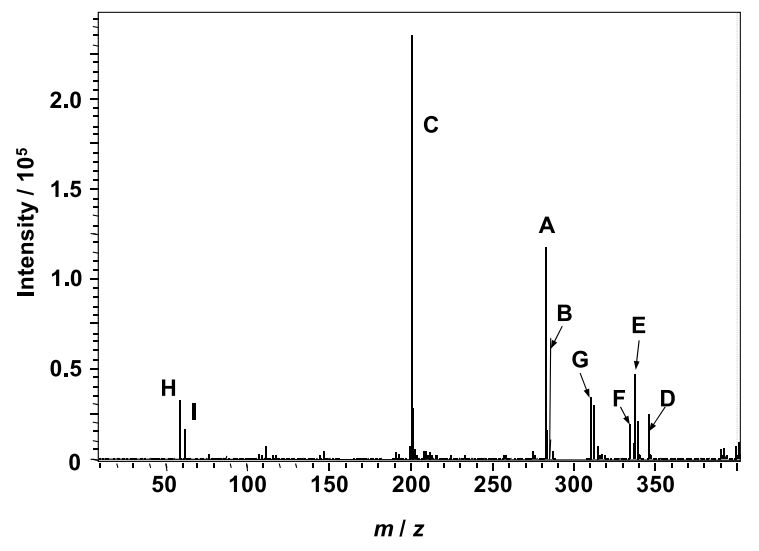

Fig. 3 ESI mass spectrum of $\left[\mathrm{Cu}^{\mathrm{II}} \mathrm{CN}(\text { par })\right]^{-}$. The sample solution

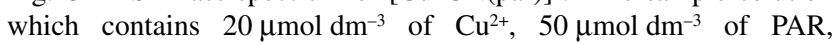
$2.5 \mu \mathrm{mol} \mathrm{dm}^{-3}$ of $\mathrm{CN}^{-}$and $1 \mathrm{mmol} \mathrm{dm}^{-3}$ of ammonium acetate was used for the ESIMS measurements. A, $\left[{ }^{63} \mathrm{Cu}^{\mathrm{II}}(\mathrm{CN})(\mathrm{par})\right]^{-}(\mathrm{m} / \mathrm{z} 302)$; B, $\left.{ }^{[65} \mathrm{Cu}^{\mathrm{II}}(\mathrm{CN})(\mathrm{par})\right]^{-}(\mathrm{m} / \mathrm{z} 304) ; \mathrm{C},[\mathrm{H}(\mathrm{par})]^{-}(\mathrm{m} / \mathrm{z} 214) ; \mathrm{D},\left[\mathrm{Co}^{\mathrm{III}}(\mathrm{edta})\right]^{-}$ (m/z 347); E, [ ${ }^{63} \mathrm{Cu}^{\mathrm{II}}\left(\mathrm{NO}_{3}\right)($ par $\left.)\right]^{-}(\mathrm{m} / \mathrm{z}, 338) ; \mathrm{F},\left[{ }^{63} \mathrm{Cu}^{\mathrm{II}}\left(\mathrm{CH}_{3} \mathrm{COO}\right)(\mathrm{par})\right]$ (m/z 335); G, $\left[{ }^{63} \mathrm{Cu}^{\mathrm{II}}{ }^{35} \mathrm{Cl}(\mathrm{par})\right]^{-}(\mathrm{m} / \mathrm{z} 311)$, and $\left[{ }^{63} \mathrm{Cu}^{\mathrm{II}}{ }^{37} \mathrm{Cl}(\mathrm{par})\right]^{-}$and $\left[{ }^{65} \mathrm{Cu}^{\mathrm{II}}{ }^{35} \mathrm{Cl}(\mathrm{par})\right]^{-}(\mathrm{m} / \mathrm{z} 313) ; \mathrm{H}, \mathrm{CH}_{3} \mathrm{COO}^{-}(\mathrm{m} / \mathrm{z}, 59) ; \mathrm{I} \mathrm{NO}_{3}^{-}(\mathrm{m} / \mathrm{z}, 62)$.

was applied to analyze a river water sample for chloride ion, which was collected from Kiryu River in Kiryu. The sample was 50-times diluted with pure water, and was directly measured by ESIMS after the addition of $200 \mu \mathrm{mol} \mathrm{dm}{ }^{-3}$ of $\mathrm{In}^{3+}$ and NTA and $1 \mathrm{mmol} \mathrm{dm}^{-3}$ of ammonium acetate. A concentration of $121 \mu \mathrm{mol} \mathrm{dm}{ }^{-3}$ for $\mathrm{Cl}^{-}$was obtained by this method, while that of $128 \mu \mathrm{mol} \mathrm{dm}-3$ was obtained by conventional IC.

ESIMS spectra of the ternary complexes of metals, cyanide and chelating agents

Cyanide ion is highly toxic, and thus the development of its trace determination method has been an important target for analytical chemists. ${ }^{11}$ We have also tried to develop a new analytical method for $\mathrm{CN}^{-}$by extending our approach. Firstly, ternary complexes of various metals and chelating agents were tested for the determination of $\mathrm{CN}^{-}$, e.g., $\mathrm{Fe}^{\mathrm{II}}$ and $\mathrm{Fe}^{\mathrm{III}}$ with various aminopolycarboxylic acids (APCs), various $\mathrm{Cu}^{\mathrm{II}}, \mathrm{Ni}{ }^{\mathrm{II}}$ and $\mathrm{Zn}^{\mathrm{II}}$ complexes, and so on. For Fe complexes, for example, we could not observe any ternary complex with $\mathrm{CN}^{-}$. For $\mathrm{Ni}^{\mathrm{II}}$ complexes, $\left[\mathrm{Ni}(\mathrm{CN})_{4}\right]^{2-}$ was always observed, even when much smaller amounts of $\mathrm{CN}^{-}$compared with those of $\mathrm{Ni}^{2+}$ and chelating agents were added. Among them, the ternary complex of $\mathrm{Cu}^{\mathrm{II}}, \mathrm{CN}^{-}$and PAR, i.e., $\left[{ }^{63} \mathrm{Cu}^{\mathrm{II}}(\mathrm{CN})(\mathrm{par})\right]^{-}(\mathrm{m} / \mathrm{z}, 302)$ and $\left.{ }^{[65} \mathrm{Cu}^{\mathrm{II}}(\mathrm{CN})(\mathrm{par})\right]^{-}(\mathrm{m} / \mathrm{z}$ 304), gave strong ESIMS signals. Although signals of the ternary complex of $\mathrm{Zn}^{\mathrm{II}}, \mathrm{CN}^{-}$and PAR, i.e., $\left[{ }^{64} \mathrm{Zn}(\mathrm{CN})(\mathrm{par})\right]^{-}(\mathrm{m} / \mathrm{z}, 303)$ were also observed by ESIMS, its signal intensity was $c a$. one twentieth of that of the $\mathrm{Cu}^{\text {II }}$ complex. Thus, we selected this $\mathrm{Cu}^{\mathrm{II}}$ complex as the target of further investigation. The measurement conditions were optimized as summarized in the Experimental section. Figure 3 shows the ESIMS spectrum of the $\mathrm{Cu}^{\mathrm{II}}$ complex, where the signals of $\left[{ }^{63} \mathrm{Cu}^{\mathrm{II}}(\mathrm{CN})(\text { par })\right]^{-}(\mathrm{m} / \mathrm{z}, 302)$ and $\left[{ }^{65} \mathrm{Cu}^{\mathrm{II}}(\mathrm{CN})(\text { par })\right]^{-}$ $(\mathrm{m} / \mathrm{z}, 304)$ ( $\mathrm{A}$ and $\mathrm{B}$ in the figure, respectively) are observed. It should be noted, however, that the ratio of the two signals $(\mathrm{B} / \mathrm{A}=c a .0 .53)$ is considerably different from that $(0.46)$ expected from the $\mathrm{Cu}$ isotope ratio, i.e., ${ }^{63} \mathrm{Cu}$ for $69.2 \%$ and ${ }^{65} \mathrm{Cu}$ for $30.8 \%$. The reason is unclear at present, and we are now trying to elucidate this phenomenon. Moreover, the signals of the ternary complex of $\mathrm{Cu}^{\mathrm{II}}$, chloride and PAR $\left(\left[{ }^{63} \mathrm{Cu}^{\mathrm{II}}{ }^{35} \mathrm{Cl}(\mathrm{par})\right]^{-}\right.$ $(\mathrm{m} / \mathrm{z}, 311)$, and $\left[{ }^{63} \mathrm{Cu}^{\mathrm{II}}{ }^{37} \mathrm{Cl}(\mathrm{par})\right]^{-}$and $\left[{ }^{65} \mathrm{Cu}^{\mathrm{II}}{ }^{35} \mathrm{Cl}(\mathrm{par})\right]^{-}(\mathrm{m} / \mathrm{z}$
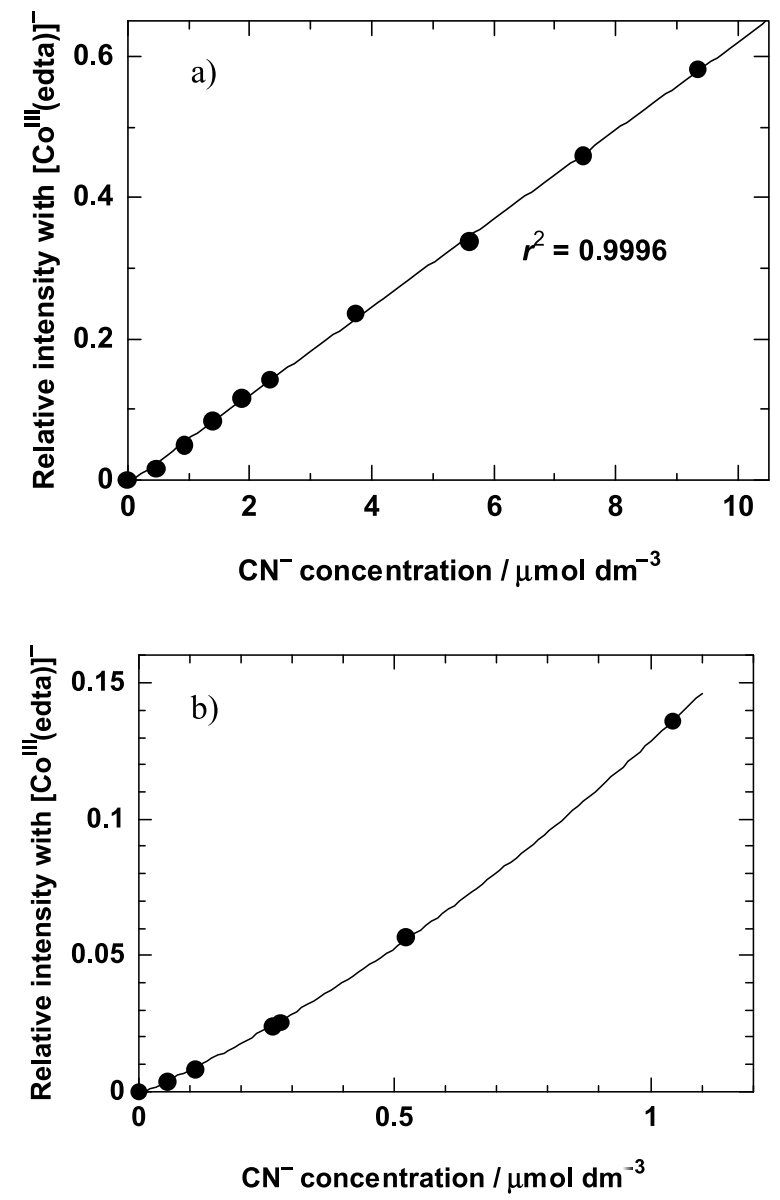

Fig. 4 Calibration curves for $\mathrm{CN}^{-}$by ESIMS with $\left[{ }^{63} \mathrm{Cu}^{\mathrm{II}}(\mathrm{CN})(\text { par })\right]^{-}$

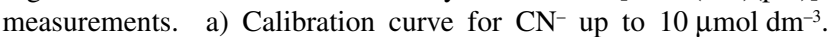
b) Calibration curve for $\mathrm{CN}^{-}$up to $1 \mu \mathrm{mol} \mathrm{dm}-3$. A sample solution containing $20 \mu \mathrm{mol} \mathrm{dm}{ }^{-3}$ of $\mathrm{Cu}^{2+}, 50 \mu \mathrm{mol} / \mathrm{dm}^{-3}$ of PAR, $1 \mathrm{mmol} \mathrm{dm}^{-3}$ of ammonium acetate, zero to $10 \mu \mathrm{mol} \mathrm{dm}{ }^{-3}$ of $\mathrm{CN}^{-}$as well as $20 \mu \mathrm{mol} \mathrm{dm}{ }^{-3}$ of $\left[\mathrm{Co}^{\mathrm{III}} \text { (edta) }\right]^{-}$as an internal standard was prepared for ESIMS measurements. The ion intensity of $\left[\mathrm{Cu}^{\mathrm{II}}(\mathrm{CN})(\mathrm{par})\right]^{-}(\mathrm{m} / \mathrm{z}, 302)$ as well as that of $\left[\mathrm{Co}^{\mathrm{III}}(\mathrm{edta})\right]^{-}(\mathrm{m} / \mathrm{z}, 347)$ were simultaneously monitored for the determination of $\mathrm{CN}^{-}$with the SIM mode.

313)), can also be seen in Fig. 3, although chloride was not intentionally added to the sample. This may mean that this ternary complex system will be applicable to determine halide ions in the future. Figure 4 shows calibration curves for $\mathrm{CN}^{-}$. Although a linear calibration curve was obtained for the higher

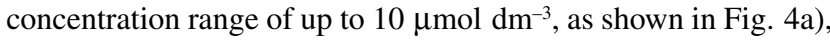
it is slightly curved in the lower concentration range than $1 \mu \mathrm{mol} \mathrm{dm}{ }^{-3}$, as also shown in Fig. 4b). The reason is unclear at present. It might be related to the stability of the ternary complex. The upper-limit of the calibration curve was changed by the concentrations of $\mathrm{Cu}^{2+}$ and PAR in the sample solutions. When $200 \mu \mathrm{mol} \mathrm{dm}{ }^{-3}$ of $\mathrm{Cu}^{2+}$ and $300 \mu \mathrm{mol} \mathrm{dm}^{-3}$ of PAR were added to the samples, a linear calibration curve was obtained at least up to $100 \mu \mathrm{mol} \mathrm{dm}{ }^{-3}$. The LODs for $\mathrm{CN}^{-}$are also summarized in Table 1. Although the ternary complex of $\mathrm{Cu}^{\mathrm{II}}$, $\mathrm{CN}^{-}$and 5-Br-PAPS, i.e., $\left[{ }^{63} \mathrm{Cu}^{\mathrm{II}}(\mathrm{CN})(5-\mathrm{Br}-\mathrm{paps})\right]^{-}(\mathrm{m} / \mathrm{z}, 545)$, also gave a linear response on $\mathrm{CN}^{-}$, its sensitivity was not as good as that of $\left[{ }^{63} \mathrm{Cu}^{\mathrm{II}}(\mathrm{CN})(\text { par })\right]^{-}$, as shown in Table 1 . The LOD of this method for $\mathrm{CN}^{-}$is as low as, or lower than, those of other reported methods for $\mathrm{CN}^{-}$. The $\mathrm{LOD}$ is about $1 \mu \mathrm{mol} \mathrm{dm}{ }^{-3}$ for both spectrophotometric methods and the ISE method, which are known as conventional methods, and are 
adopted as official methods for $\mathrm{CN}^{-} .^{11,12}$ Thus, the present method is about 50-times as sensitive as such methods. Moreover, the LOD of the present method is comparable to those of the latest reported methods, ${ }^{11}$ e.g., chemiluminescence methods (LODs, 4 to $200 \mathrm{nmol} \mathrm{dm}^{-3}$ ), fluorometric methods ( 0.2 to $2.5 \mu \mathrm{mol} \mathrm{dm}^{-3}$ ), GC-MS methods (LODs, 0.2 to $0.4 \mu \mathrm{mol} \mathrm{dm}^{-3}$ ), GC-ECD (LOD, $20 \mathrm{nmol} \mathrm{dm}^{-3}$ ), ESI-MS/MS (LOD, $\left.40 \mathrm{nmol} \mathrm{dm}^{-3}\right),{ }^{6} \mathrm{IC}-\mathrm{PAD}$ (pulsed amperometric detection) (LOD, $40 \mathrm{nmol} \mathrm{dm}^{-3}$ ), and amperometry (LOD, 2 to $4 \mathrm{nmol} \mathrm{dm}-3$ ). Thus, the present method could be classified as one of the most sensitive methods for $\mathrm{CN}^{-}$at present. This method has not yet been applied to analyze any real sample. Although concomitant ions in samples should interfere with the ESIMS measurements to a certain extent, such interferences could be removed by appropriate sample pretreatments. For example, the on-line size exclusion column described in Ref. 8 and/or distillation process, which is the standard method for $\mathrm{CN}^{-}$determinations, ${ }^{12}$ would be useful for this purpose.

\section{Conclusions}

We developed determination methods of halide ions $\left(\mathrm{X}^{-}=\mathrm{F}^{-}\right.$, $\mathrm{Cl}^{-}, \mathrm{Br}^{-}$and $\mathrm{I}^{-}$) by electrospray ionization mass spectrometry (ESIMS), where negative ions of the ternary complexes of group-13 elements, nitrilotriactic acid (NTA), and halides were measured. In particular, these halides were simultaneously determined by measuring $[\mathrm{InX}(\mathrm{nta})]^{-}$, and very low LODs were obtained for $\mathrm{Br}^{-}$and $\mathrm{I}^{-}$, i.e., $3.8 \mathrm{nmol} \mathrm{dm}^{-3}$ for $\mathrm{Br}^{-}$, and $1.6 \mathrm{nmol} \mathrm{dm}^{-3}$ for $\mathrm{I}^{-}$, respectively. Moreover, this approach was extended to the determination of $\mathrm{CN}^{-}$, where the ternary complex of $\mathrm{Cu}^{\mathrm{II}}, \mathrm{CN}^{-}$and PAR, i.e., $\left[\mathrm{Cu}^{\mathrm{II}}(\mathrm{CN})(\text { par })\right]^{-}$was measured and the LOD for $\mathrm{CN}^{-}$was $20 \mathrm{nmol} \mathrm{dm}^{-3}$. The present methods are easy to perform, and are highly sensitive and selective mainly because they are based on direct mass spectrum measurements of stable complexes containing analyte ions. Thus, they may be useful for the determination of halides and cyanide ions in actual samples, such as environmental and biological samples in the future.

\section{Acknowledgements}

This work was partly supported by a Steel Foundation for the Environmental Protection Technology (SEPT) (Nos. C-33-26 and $\mathrm{C}-30-25)$ to $\mathrm{HH}$, for which we are grateful.

\section{References}

1. A. Seubert, G. Schminke, M. Nowak, W. Ahrer, and W. Buchberger, J. Chromatogr., A, 2000, 884, 191.

2. P. K. Martinelango, J. L. Anderson, P. K. Dasgupta, D. W. Armstrong, R. S. Al-Horr, and R. W. Slingsby, Anal. Chem., 2005, 77, 4829.

3. P. K. Martinelango and P. K. Dasgupta, Anal. Chem., 2007, 79, 7198.

4. R. J. Soukup-Hein, J. W. Remsburg, P. K. Dasgupta, and D. W. Armstrong, Anal. Chem., 2007, 79, 7346.

5. J. Wang and W. C. Schnute, Rapid Commun. Mass Spectrom., 2009, 23, 3439.

6. K. Minakata, H. Nozawa, K. Gonmori, M. Suzuki, and O. Suzuki, Anal. Chim. Acta, 2009, 651, 81.

7. K. Minakata, I. Yamagishi, S. Kanno, H. Nozawa, M. Suzuki, and O. Suzuki, J. Chromatogr., B, 2010, 878, 1683.

8. H. Hotta, T. Mori, A. Takahashi, Y. Kogure, K. Johno, T. Umemura, and K. Tsunoda, Anal. Chem., 2009, 81, 6357.

9. The Japan Society for Analytical Chemistry, "Bunsekikagaku Binran (in Japanese)", 5th ed., 2001, Maruzen, Tokyo.

10. JIS K0400-35, “Water Quality-Determination of Dissolved Fluoride, Nitrite, Orthophosphate, Bromide, Nitrate and Sulfate Ions, Using Liquid Chromatography of Ions", 1999, Japanese Industrial Standards Committee, Tokyo.

11. J. Ma and P. K. Dasgupta, Anal. Chim. Acta, 2010, 673, 117.

12. JIS K0400-38, "Water Quality—Determination of Cyanide", 1999, Japanese Industrial Standards Committee, Tokyo. 